\title{
Biomarkers for pediatric pulmonary arterial hypertension - a call to collaborate
}

\section{Kelley L. Colvin ${ }^{1,2,3,4}$, Melanie J. Dufva ${ }^{1,2 \dagger}$, Ryan P. Delaney ${ }^{1,2 \dagger}$, D. Dunbar Ivy ${ }^{5}$, Kurt R. Stenmark ${ }^{2,3}$ and Michael E. Yeager ${ }^{1,2,3,4 *}$}

${ }^{1}$ Department of Bioengineering, University of Colorado Denver, Aurora, CO, USA

2 Department of Pediatrics-Critical Care, University of Colorado Denver, Aurora, CO, USA

${ }^{3}$ Cardiovascular Pulmonary Research, University of Colorado Denver, Aurora, CO, USA

${ }^{4}$ Linda Crnic Institute for Down Syndrome, University of Colorado Denver, Aurora, CO, USA

${ }^{5}$ Children's Hospital Denver, Aurora, CO, USA

\section{Edited by:}

Michael David Shields, Queen's

University Belfast, Northern Ireland

Reviewed by:

Nael McCarty, Emory University

School of Medicine, USA

Ignacio Tapia, The Children's Hospital of Philadelphia, USA

Michael David Shields, Queen's

University Belfast, Northern Ireland

${ }^{*}$ Correspondence:

Michael E. Yeager, Departments of Bioengineering and Pediatrics-Critical

Care, Cardiovascular Pulmonary

Research, Linda Crnic Institute for

Down Syndrome, University of

Colorado Denver, 12700 East 19th

Avenue, Box B131, Aurora, CO

80045, USA

e-mail:michael.yeager@ucdenver.edu

${ }^{\dagger}$ Melanie J. Dufva and Ryan P.

Delaney have contributed equally to

this work.
Therapeutic approaches in pediatric pulmonary arterial hypertension (PAH) are based primarily on clinician experience, in contrast to the evidence-based approach in adults with pulmonary hypertension. There is a clear and present need for non-invasive and objective biomarkers to guide the accurate diagnosis, treatment, and prognosis of this disease in children. The multifaceted spectrum of disease, clinical presentation, and association with other diseases makes this a formidable challenge. However, as more progress is being made in the understanding and management of adult PAH, the potential to apply this knowledge to children has never been greater. This review explores the state of the art with regard to non-invasive biomarkers in $\mathrm{PAH}$, with an eye toward those adult $\mathrm{PAH}$ biomarkers potentially suitable for application in pediatric $\mathrm{PAH}$.

Keywords: pulmonary arterial hypertension, pediatric, biomarkers, imaging, magnetic resonance, echocardiography, right ventricle

\section{INTRODUCTION}

Our understanding of pulmonary hypertension $(\mathrm{PH})$ in children has been hampered over the years by a number of factors. Despite the important benefits of off-label application to children of PH therapies originally developed for adults, the disease remains lethal. The study of $\mathrm{PH}$ in children is further complicated by additional factors such as the complexity of accurate diagnosis, the multifactorial nature of the disease, and a relatively poor understanding of the natural history of the disease. The need for earlier detection, more accurate and sensitive biomarkers of disease and disease progression, and a personalized approach to therapy cannot be overstated. To date, biomarker reviews for $\mathrm{PH}$ have focused on adults. This review focuses on the unrealized promise of biomarkers in pediatric $\mathrm{PH}$, their potential to improve our ability to

Abbreviations: CEC, circulating endothelial cell; CHD, congenital heart disease; CT, computed tomography; EC, endothelial cell; Echo, echocardiography; EPC, endothelial progenitor cell; MRI, magnetic resonance imaging; $\mathrm{PAH}$, pulmonary arterial hypertension; $\mathrm{PET}$, positron emission tomography; $\mathrm{PH}$, pulmonary hypertension; PVR, pulmonary vascular resistance; RHC, right heart catheterization; RV, right ventricle; SPECT, single photon emission computed tomography; TDI, tissue Doppler imaging. treat $\mathrm{PH}$, and the capacity for adult biomarkers of $\mathrm{PH}$ to be applied to children.

\section{DEFINITION AND CLASSIFICATION OF PEDIATRIC PULMONARY HYPERTENSION}

Pulmonary hypertension is a condition characterized by increased blood pressure and resistance in the arterial vasculature of the lung as the result of numerous pathological mechanisms, eventually culminating in right ventricular failure. The development of the disease may be linked to other diseases as a derived secondary disease, or may develop solitarily with known etiology, or may be idiopathic (1). PH may develop in both children and adults, regardless of age. Currently, as elaborated by the World Health Organization Dana Point 2008 Clinical Classification system, there are five categories of $\mathrm{PH}$, with the most common form of childhood PH (amounting to $~ 90 \%$ of cases) occurring in Group I (1). Group I, denoted as pulmonary arterial hypertension (PAH), includes idiopathic (IPAH), familial (FPAH), PAH associated with venous and/or capillary disorders, or associated with other diseases (APAH), including HIV infection, drugs, toxins, congenital shunts between pulmonary and systemic circulation, collagen vascular disease, and others. Groups II-V are categorized as PH associated 
left heart disease, $\mathrm{PH}$ associated with lung diseases/hypoxia, $\mathrm{PH}$ due to embolic and/or chronic thrombotic disease, and $\mathrm{PH}$ associated with miscellaneous conditions, respectively.

Current standards define PAH in adults and children in a similar way, with specified parameters of a mean pulmonary artery pressure $\geq 25 \mathrm{mmHg}$, a normal capillary wedge pressure $\leq 15 \mathrm{mmHg}$, and an increased pulmonary vascular resistance (PVR) (2). The minimum value for increased PVR remains controversial, especially in pediatric patients, where $\mathrm{PAH}$ caused by left-to-right congenital shunts is common, and in such cases no significant increase in PVR is observed (3). Therefore, most experts suggest a PVRI $\geq 3 \mathrm{WUm}^{2}$ for diagnosis of pediatric PAH (3). When left untreated, children with PAH are predicted to have lower survival rates and poorer prognosis than adults (4). Abnormal lung and cardiac development is known to play a factor in pediatric $\mathrm{PAH}$, in which left-to-right shunts due to congenital heart defects causes increased flow in the pulmonary vasculature, known as the Eisenmenger syndrome (5). Studies have shown the pathophysiology for PAH to be comparable between children and adults (6-8), yet there remains limited data on the efficacy of current adult therapies extrapolated to children. Pediatric $\mathrm{PAH}$ is a rare, multifactorial disease, with no current cure. Therefore, there is a need to standardize prognostic procedures for the establishment of early and appropriate therapeutic responses.

Clinically, children with $\mathrm{PAH}$ show various symptoms, may be non-specific, and are dependent upon age. Symptoms include shortness of breath, exercise fatigue, respiratory symptoms and chest pain (9). Current diagnostic methods include echocardiography (Echo), exercise testing, right heart catheterization (RHC), and vasodilator testing for both adults and children (10). In children in whom RHC is deemed unsuitable, the diagnosis is usually reached as a validated consensus from a team of pediatric $\mathrm{PH}$ specialists. And subsequent therapy is based on similar algorithms used in adults as well as the experience of the clinical team (11).

\section{EPIDEMIOLOGY AND WORLDWIDE HEALTH BURDEN OF PH}

For adults with $\mathrm{PAH}$, studies have reported an incidence of 7.6 per million cases of adults per year and a prevalence of 52 cases per million (12). Limited data are available on disease registries of pediatric $\mathrm{PAH}$, due to small patient numbers, and because earlier registries lack standardized assessments (4). However, recently, a number of studies have been completed for disease registry and to further improve understanding of the disease epidemiology in children (13). PAH in children is rarer than in adults. Data from a registry in the Netherlands reported the incidence of pediatric PAH to be 63.7 cases per million children, with a majority of those cases being PAH diagnosed (57.9 cases per million children) (14), a comparable incidence to that seen in adults. In a study conducted by the UK Pulmonary Hypertension Service for Children, survival rates for PAH diagnosed children, treated with modern therapies (mono- or combination therapies, or disease-specific therapy, including treatment with calcium channel blockers, bosentan, and intravenous epoprostenol), were reported at $\sim 90.5,82.8$, and $64.2 \%$, at 1,3 , and 5 years, respectively (15). Another study conducted by the Registry to Evaluate Early and Long-Term PAH Disease Management (REVEAL) reported survival rates of IPAH/FPAH and APAH-CHD children, treated with etiologic specific therapies, at 96,84 , and $74 \%$ for 1,3 , and 5 years, respectively (16). These data are supported by results in similar studies $(14,17,18)$. Data show varying survival estimate differences between IPAH and APAH patients (14-16), which may be due to limited sample sizes and various subgrouping analysis. Compared to adults, data from the Tracking Outcomes of Pediatric Pulmonary Hypertension (TOPP) showed a higher distribution of APAH associated with CHD in children, with a very low occurrence of PAH associated with tissue diseases, HIV, drugs, and portopulmonary hypertension (19). A higher occurrence of the disease in children has been observed in females than males at a $2: 1$ ratio (20), which is lower compared to the $4: 1$ ratio seen in adult patients (21).

The recent data from these registries report preliminary findings on the efficacy of adult therapies in children, with positive improvements in the prognosis. Though adults and children with PAH have shown similar pathobiology and clinical responses to treatment therapy, much is still unknown about pediatric $\mathrm{PAH}$, and full elucidation of the differences between adults and children still remains.

\section{BIOMARKER DEFINITION}

The National Institutes of Health defines a biomarker as: "a characteristic that is objectively measured and evaluated as an indicator of normal biologic processes, pathogenic processes, or pharmacologic responses to therapeutic intervention" (22). This broad definition is particularly apt for pediatric diseases, which may involve developmental disturbances with and without pathogenic and pharmacologic processes. Recently, several excellent reviews on biomarkers in adult PAH have been published (23-25). This review focuses on those biomarkers that have been proposed for, or may have specific relevance to, pediatric $\mathrm{PAH}$.

\section{GENERAL BIOCHEMICAL CLASSES OF PULMONARY HYPERTENSION BIOMARKERS}

The ultimate biomarker for any disease would be one that involves a procedure that is easy to perform, painless, inexpensive, while offering high specificity, and low rates of false negatives and positives. For a biomarker to be effective in a pediatric population, additional factors such as patient compliance must be considered. During the typical patient workup, many routine tests are ordered that can serve as biomarkers. Some sources, such as plasma, could potentially be screened to simultaneously measure panels of biomarkers. Indeed, there is unlikely to be any single biomarker for PAH that perfectly satisfies all of these requirements. Furthermore, in the age of "personalized medicine," biomarkers may be of better value when measured and compared longitudinally in a single patient, rather than compared to others as absolute values at single time points. As a starting point, $\mathrm{PAH}$ is a hemodynamic definition, representing a spectrum of diseases that ultimately leads to right heart failure. Therefore, biomarkers for PAH should correlate in some fashion to a hemodynamic measurement such as PA pressure, PA wedge pressure, PVR, etc., and/or to a clinical measurement such as survival, pulmonary function test, etc. (Figure 1) (23).

The pathobiology of PAH is multifactorial and complex. Therefore, it should not be surprising that potential biomarkers likely should reflect aspects of the underlying disease process (Figure 1). 


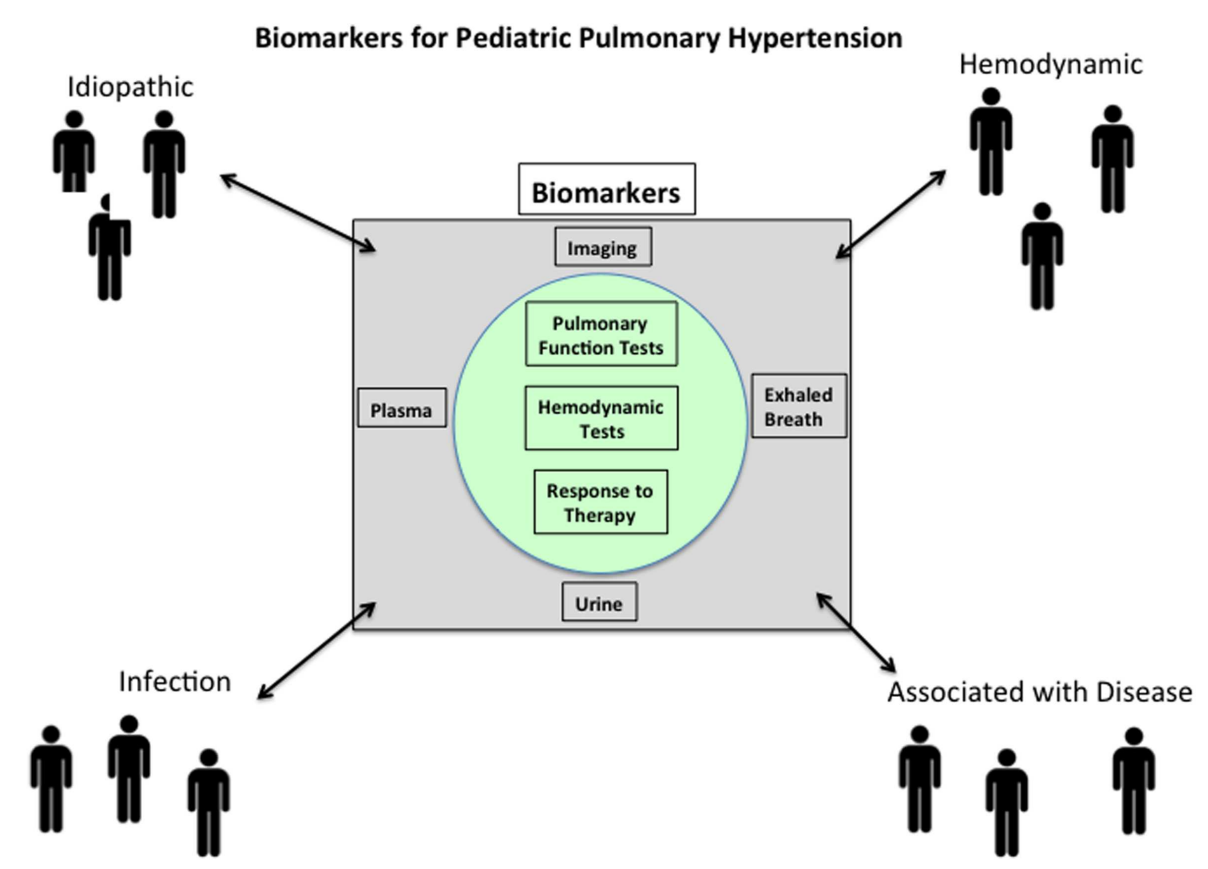

FIGURE 1 | Pulmonary arterial hypertension (PAH) is a syndrome that is idiopathic in origin or arises in association with a large number of disease processes. Biomarkers for $\mathrm{PAH}$ should correlate in some fashion to a hemodynamic measurement such as PA pressure, PA wedge pressure, pulmonary vascular resistance, etc., and/or to a clinical measurement such as survival, pulmonary function test, etc. Since the pathobiology of PAH is multifactorial and complex, it should not be surprising that potential biomarkers will likely reflect aspects of the underlying disease process.
Damage to pulmonary endothelium and ongoing endothelial cell (EC) dysfunction is thought to play a fundamental role in the pathogenesis of PAH (26). Many of the therapies used in patients with $\mathrm{PH}$ relate to the biology of dysfunctional endothelium by targeting prostaglandins, nitric oxide, and endothelins (23). Inflammation in the lungs and right ventricle is thought to play significant roles in the pathobiology of PAH $(27,28)$. Mast cells, monocytes, macrophages, T cells, and B cells have all been shown to participate at some level in PAH (29). Both innate and acquired immune cells are rich sources of cytokines and chemokines that have been reported to be prognostic biomarker in adult PAH (23). The larger question of whether these inflammatory markers are indicators of general inflammation and oxidative stress or whether they are specific for pulmonary vascular disease and/or right ventricle dysfunction is not known. In addition, significant variability in the levels of some cytokines (ex: IL-6) has been reported $(30,31)$, likely due to differences in patient cohorts and in assay methodology. These reproducibility issues must be resolved before their widespread acceptance and use in the clinic. Finally, biomarkers of heart dysfunction have been increasingly used to evaluate and often prognosticate PAH. This is evidenced by a PubMed search conducted in January 2014 using the terms "biomarkers right ventricle pulmonary hypertension," which resulted in 90 hits with 52/90 published in the last 5 years [four excellent examples (32-35)]. Measurement of atria natriuretic peptide (ANP) and most especially B-type natriuretic peptide (BNP) and N-terminal (NT)-proBNP provide important and reproducible prognostic markers with regard to cardiac function vis-à-vis blood volume and pressure (36).

\section{SPECIFIC CLASSES OF PULMONARY HYPERTENSION BIOMARKERS}

For the purposes of this review, we exclude invasive hemodynamics but include as a biomarker, any modality that yields data that can aid in assessment of PAH at any point in its course. Such a perspective admittedly ignores real-world limitations of resources, expertise, and the recruitment of sufficiently large enough patient cohorts. Specific classes of biomarkers for PAH can be organized into those arising from imaging tests, circulating biomarkers, exhaled breath, and urinary biomarkers.

\section{IMAGING TESTS}

Echocardiography

The gold standard for assessment of PAH is RHC, in which mean pulmonary artery pressure (pa), cardiac output, and PVR measurements can be obtained (37). Three recent reviews provide excellent summaries of RHC (38-40). Prior to invasive hemodynamics, an echocardiogram is almost always performed. Echo is an important screening tool for the diagnosis of $\mathrm{PAH}$, and is also the standard of care for non-invasive monitoring of $\mathrm{PH}$ progression. Echocardiographic findings, although subject to significant operator variability (41), reliably provide several estimates of hemodynamic function that closely correlate with measurements obtained by RHC. A large variety of estimates of RV function can be made, depending on assumptions of RV geometry. Flattening and inversion of the inter-ventricular septum toward the left ventricle is highly suggestive of PAH (42). Detailed echocardiographic methodology and the equations used for calculation of variables are detailed elsewhere (43). Recently, the importance of Doppler 
Echo based measurement of the acceleration time of pulmonary flow has become an important metric, as has the tricuspid annular plane systolic excursion (TAPSE) (44). Decreased TAPSE has been associated with poor prognosis in patients with dilated cardiomyopathy, and may have correlation with pa and PVR (45). Recently, tissue Doppler imaging (TDI) has been used to predict adverse outcome in children with IPAH (46). This approach measures three waveforms that represent the cardiac cycle: systolic myocardial velocity $(\mathrm{Sm})$, early diastolic myocardial relaxation velocity (Em), and late diastolic myocardial velocity associated with atrial contraction (Am). This prospective study compared 51 children with IPAH to 51 controls and found that tricuspid Em had higher correlation with plasma BNP levels and hemodynamics than tricuspid Sm. These findings differed with those from adults (47-49), but, importantly, support our thesis that biomarkers in adults with $\mathrm{PH}$ should be systematically and comparatively examined in children with PAH. As with nearly all studies of pediatric $\mathrm{PAH}$, interpretation of the study is constrained by the relatively small sample size. In addition, the patients were placed on vasodilators suited to their particular clinical portraits and all survived, and so the ability of TDI to predict mortality was not assessed. Nevertheless, this prospective study illustrates the power of non-invasive testing by Echo as part of the biomarker toolkit of the pediatric cardiologist.

\section{Computed tomography}

Multi-detector computed tomography (CT) is used routinely to assess both cardiovascular and lung parenchymal changes in patients with PAH. With the advent of respiration-timed CT gating with electrocardiography, the technique has vastly improved (50). As much as its value has improved, correlation with measurements such as main pulmonary artery diameter to pa is variable (51-53). However, several studies have used CT imaging to establish the differential diagnosis of PAH by ruling in or out associated pathologies such as pulmonary thromboembolism or pulmonary fibrosis. Recent work has begun to demonstrate good correlation between functional parameters such as right pulmonary artery wall distensibility and diagnosis of $\mathrm{PAH}$ (54). As respiration gating improves along with increasing image detail, CT will continue to be an important assessment tool for the diagnosis of $\mathrm{PH}$. By far the largest drawback to the use of CT is exposure to X rays. Not only does this limit the capacity for CT to provide longitudinal study data, its use in children is problematic and the benefits must be weighed against exposure time. For example, the contrast agents used are associated with kidney injury (55). Furthermore, patient compliance (inability to hold still, claustrophobia, etc.) in a pediatric population can be problematic.

\section{Single photon emission computed tomography}

Single photon emission computed tomography (SPECT) is a variation in CT in which gamma rays emitted from an injected radionuclide source are detected by a rotating gamma camera (56). The technique allows for three-dimensional reconstruction, and when used with specific radioligands, tissues of interest can be closely scrutinized. Of particular interest is the ability to measure true perfusion with Technetium-99m labeled macro-aggregated albumin (57). Unfortunately, acquisition of SPECT images typically takes several minutes and breathing during acquisition affects image resolution, yet has been performed successfully in animal models of PAH (58). As with CT, respiration gating improves image quality. In any case, the ability to perform SPECT in pediatric lung disease is limited, but the promise of three-dimensional reconstructions of perfused lung vasculature is enticing.

\section{Positron emission tomography}

Positron emission tomography (PET) has seen a dramatic increase in use over the past decade in the setting of PH. Recently, it was shown that PAH hearts have pathologic glycolytic metabolism that is quantitatively related to cardiac dysfunction over time (59). Interestingly, the FDG uptake observed also seemed to correlate with circulating CD34+CD133+ cells (a class of biomarker discussed in the next section). Breath-gated PET had moderate-tohigh correlation with cardiac magnetic resonance (CMR) imaging and $\mathrm{CT}$ in the assessments of RV volume and ejection fraction (60). FDG uptake by the RV reflects the severity of PVR in PAH. Increased RV FDG uptake is a marker of poor prognosis in IPAH and is reduced in patients receiving effective therapy (61). What is somewhat unclear is the extent to which FDG PET in patients with PAH truly measures increased cellular metabolism or reflects inflammatory processes. One study recently reported that there were no correlations between (18) FDG uptake and hsCRP or inflammatory cytokine levels in PAH patients. However, NT-ProBNP correlated with RV uptake in those with PH suggesting that FDG PET may be a good biomarker for RV dysfunction (62). In experimental $\mathrm{PH}$, Glut1 up-regulation in proliferating vascular cells in PAH accounts for increased lung FDG PET uptake. FDG PET is sensitive to mild PAH and can monitor therapeutic changes in the vasculature (63). Collectively, these studies strongly suggest that metabolic imaging may be useful in therapeutic monitoring of PAH patients. In adults, PET appears to be a suitable method for assessing RV function and myocardial glucose metabolism in patients with $\mathrm{PAH}$, as well as lung metabolic and cellular proliferation.

For CT, SPECT, and PET, important considerations regarding radiation dose vis-à-vis diagnostic benefits must be carefully weighed. However, the value of nuclear medicine in pediatrics is well established, as has standard dosimetry for a large variety of radiopharmaceuticals (64).

\section{Magnetic resonance imaging}

Cardiac magnetic resonance imaging (MRI) has rapidly evolved to be a powerful tool to measure right ventricular morphology, and volumes and ejection fractions (65-69). The ventricular mass index, which is the quotient of right ventricular mass over left ventricular mass, is highly sensitive and specific for prognosticating PAH [reviewed in Ref. (70)]. Furthermore, its advantages in spatial resolution, lower intra-operator variability, and true threedimensionality make it the gold standard for RV study over Echo (71). Cardiac MRI has been successfully used to determine RV stroke volume index, RV ejection fraction, RV mass, RV isovolumic relaxation time, leftward ventricular septal bowing, and left ventricular ejection fraction (72). With regard to children with $\mathrm{PH}$, MR can be performed safely and effectively. In one study of 26 subjects, markedly abnormal RVs were found (73). One year later, no 
change in cardiac MR parameter was observed, which highlights the advantage of MR for serial testing. Additional morphological and functional parameters could be measured in children to include inter-ventricular septum configuration, stress testing, fibrosis (with late gadolinium enhancement), and pulmonary circulation testing (74). A detailed treatment of the wide range of potential uses for MRI in normal and PAH lung has been published (75). Recently, the prognostic value of MR was evaluated in 100 children with PAH, of which 60 were diagnosed with IPAH (76). Almost all parameters assessed by MR correlated with clinical metrics of disease severity and had strong correlation to invasively measured pa. Detailed MRI assessment of heart and lung function in children with $\mathrm{PH}$ at initial workup and serially in the course of treatment will be an increasingly important tool for the clinician.

\section{CIRCULATING BIOMARKERS}

Blood is a potentially rich source of biomarkers in the setting of pediatric $\mathrm{PAH}$. Since $\mathrm{PAH}$ is a multifactorial and complex vascular disorder, it stands to reason that a variety of biomarkers would be present arising from sources related to ongoing processes of inflammation, coagulation, and ventricular strain. For this review, we have divided blood biomarkers into compartments of cells and non-cells (plasma or serum). Within the cellular compartment, leukocytes, erythrocytes, and platelets are routinely analyzed in the hospital laboratory setting. Recent studies have measured microparticles, circulating endothelial cells (CECs), and endothelial progenitor cells (EPCs) in peripheral and/or central blood. In addition, a substantial number of chemokines, cytokines, and even RNAs have been measured in the blood plasma and correlated to physiological and clinical parameters of $\mathrm{PAH}$, mostly in adults.

\section{Cells and microparticles}

Many disease states are characterized by increase or decrease in circulating cells, often those involved in inflammation (77) or angiogenic responses to injury/repair (78). $\mathrm{PH}$, at least in adults, is associated with EC dysfunction (79). CEC as well as EPC are readily identifiable in adults with PAH $(80,81)$. Microparticles, defined as plasma membrane fragments between 0.1 and $1 \mu \mathrm{m}$ in diameter, are released during a number of physiologic and pathophysiologic conditions by numerous cell types (82). Recently, CECs were prospectively measured in children with IPAH and PAH secondary to congenital heart disease, before and after treatment (83). Importantly, rising CEC counts preceded clinical deterioration, suggesting that CECs may be an important tool to anticipate clinical worsening. Another study on endothelial biomarkers reported elevated levels of circulating ECs associated with reversible APAH-CHD in children, suggesting that endothelial dysfunction and damage play an important role in angiogenesis (84). This study also included analysis of soluble markers, and results showed that levels of angiogenic cytokine, inflammation, or endothelial microparticles were not predictors of $\mathrm{PAH}$ reversibility. Additional studies by Smadja et al. showed that harvested endothelial colony forming cells (ECFCs) from peripheral blood of children with IPAH and APAH-CHD had a hyperproliferative phenotype with enhanced angiogenic potential when treated with prostanoid therapy (treprostinil) in a nude preclinical mouse model of limb ischemia (85). These results provide support for the importance of EPCs in vascular repair in pediatric PAH. On the other hand, some studies have failed to establish any correlation between circulating EPC and pa (86). Small sample sizes, observer bias, or differences in technical approach may explain such disparate results. Flow cytometric assessment of circulating microparticles derived from platelet and erythrocytes in young thalassemia major patients positively correlated to markers related to $\mathrm{PH}$ and aortic wall stiffness (87). In a small study, microparticles form PAH patients were shown to have increased CD39 nucleotidase activity (88). Thus, circulating vascular cells, or microparticles derived from them, appear to be variable in number in PAH patients, may or may not correlate to clinical values, and may be involved in the pathogenesis. Whether measured in children or adult with $\mathrm{PAH}$, a multi-center study with a large cohort, using a standardized methodology for a specified set of markers, should definitively establish the utility of vascular cell measurement as a biomarker.

In addition to vascular cells, inflammatory cells can be measured in peripheral blood. Deficiencies in natural killer cells and cytotoxic CD8 $+\mathrm{T}$ cells may portend risk of death in $\mathrm{PAH}$ patients (89). Compared to controls, individuals with $\mathrm{PH}$ and pulmonary veno-occlusive disease (PVOD) have decreased circulating T lymphocytes (90). In that study, epigenetic alterations of the granulysin gene discriminated PVOD from PAH. In yet another study, peripheral blood mononuclear cells (PBMCs) were purified and analyzed for expression of endoplasmic reticulum stress and unfolded protein response markers (91). Compared to controls, PAH patients' PBMC had higher expression of these markers, which in the case of the unfolded protein response effectors DnaJB and BiP, correlated to inflammation (IL-6 levels) and disease severity (pa). Importantly, these studies seem to corroborate an emerging concept of cell stress in PAH that is being borne out in animal models of PAH (92). These results provide evidence that analysis of circulating white blood cells by flow cytometric quantification and subsequent gene expression characterization represent potentially important blood tests that could be integratively applied to current diagnostic and prognostic workups in children with PAH. Indeed, elevations of subsets of monocytic cell subsets have been identified in children with PAH $(93,94)$. Such studies, if confirmed in additional cohorts, could be prospectively expanded and performed serially to establish correlations to inflammation, disease progression, and response to therapy. During the clinical workup, numerous opportunities are available to measure circulating cells and microparticles, either centrally at catheterization or peripherally.

\section{Plasma}

The plasma has been investigated in both adult and pediatric $\mathrm{PAH}$ patients for a large number of biomolecules, including proteins, vitamins, and nucleic acids. As with circulating cells, it is thought that biomolecules in the plasma likely reflect underlying disease processes of lung vascular cell dysfunction (95), ventricular damage (96), and inflammation (97).

\section{Plasma proteins}

As mentioned above, NT-proBNP is probably the most studied (measured) plasma protein biomarker in PAH. In children, as is 
the case with adults, NT-proBNP has prognostic value $(98,99)$. The levels of NT-proBNP have been reported to be lower in children with $\mathrm{PH}$ than in adults $(100,101)$, a finding which seems to correspond with a decreased incidence of right heart failure in children vs. adult patients. Similarly, cardiac troponin $\mathrm{T}$ is an independent marker of mortality (102). A critically important aspect to consider in the pediatric PAH patient is age and/or stage of development. Indeed, children are not "small adults." Developmental programs driving lung vessels are thought to be perturbed in $\mathrm{PAH}$, and decreased plasma vascular endothelial growth factor (VEGF) in infants with PAH may be a reflection of such disturbances (103). Recent proteomic studies have demonstrated clear feasibility in measuring plasma interleukins (ILs), acute phase proteins, and growth factors $(104,105)$. Some of these plasma proteins may simply reflect systemic inflammation (serum amyloid A), but may also be mechanistically linked to control of inflammatory cell phenotype (serum amyloid P). For example, mast cells have long been implicated in the pathobiology of $\mathrm{PH}$ and efforts to understand their specific contributions have recently been re-energized (29). Growth differentiation factor (GDF)-15 (106), Endothelins (107), and C-reactive protein (108) appear promising as biomarkers in adult $\mathrm{PH}$, at least with respect to inflammation. Recently, blood and urine leukotriene E4, proangiogenic factors, mast cell numbers, and mast cell tryptase levels were higher in $\mathrm{PAH}$ patients, and receded subsequent to treatment with mast cell inhibitors cromolyn and fexofenadine (109). However, these declines were not linked to clinical improvement. Nevertheless, this study provides a representative framework to perform a comprehensive (multicompartment, multi-target) biomarker analysis that could be applied to children with PAH. Another study analyzing the relationship between hemodynamics and serum levels of intracellular adhesion molecule 1 (sICAM-1) showed that levels are elevated in children with APAH-CHD compared to children with only congenital heart disease, with mean pulmonary arterial pressure being the strongest independent predictor (110). Collectively, a large number of plasma proteins could be systematically evaluated in children with PAH. We suggest a multiplex platform, as we have used (104), but one in which the protein targets have been customized to a " $\mathrm{PH}$ plasma proteome signature" likely comprised of IL-6, GFF-15, sICAM-1, endothelins, serum amyloid A, and serum amyloid P. High accuracy/high precision multiplex assay platforms are already routinely capable of measuring $>84$ analytes with appropriate controls on a single 96-well plate. Because of this large analytic capacity, the choice of biomarkers to analyze might be less important as the choice to systematically adopt it. Development of close collaboration between biotechnology industry, academia, and biopharma seems particularly suited for the task of biomarker selection, analysis, and scope of interpretation. We offer a comprehensive recommendation for specific biomarkers in the conclusion section of this review.

\section{Plasma non-proteins}

There have been a large number of studies that have identified differences in levels of plasma non-proteins between $\mathrm{PAH}$ patients, PAH patient sub-groups, and controls [reviewed in Ref. (111)]. For this review, we have focused on vitamins and RNA species as non-protein biomarkers, but the complete list is much longer and beyond our scope here.

Vitamins. Vitamins are a large and diverse group of organic compounds that are essential for normal growth and nutrition and are required in small quantities in the diet because they cannot be synthesized by the body. There have been a large number of studies that have identified differences in plasma vitamin levels between $\mathrm{PAH}$ patients, $\mathrm{PAH}$ patient sub-groups, and controls. Curiously, there are very few reviews available that summarize potential roles of vitamins in PAH. For one example, Vitamin D levels affect the renin-angiotensin-aldosterone system, which, in turn, affects the cardiovascular system. Low Vitamin D levels correlated with higher systolic PA pressure (112). As a large number of $\mathrm{PAH}$ patients are therapeutically anti-coagulated, appropriate levels of Vitamin K are critically important due to major bleeding risks (113). Vitamin B12 (cobalamin C) deficiency may be associated with, or predispose individual to, pediatric PAH (114). Vitamin B1 (thiamine) deficiency is a cause of wet (cardiac) beriberi (115), which often manifests with symptoms of PAH (116). Finally, Vitamin C deficiency (117), elevated plasma copper (118), and iron deficiency (119) all appear to be associated with the development of $\mathrm{PH}$. In the case of iron, its measurement as a biomarker can be extended by measurement of red cell distribution width, which is predictive for mortality in PAH patients (120). Unfortunately, the studies examining levels of vitamins in the setting of PAH are sporadic and involve small numbers and/or anecdotal cases. Furthermore, the efficacy of vitamin therapies (nutraceuticals) in PAH is questionable. With regard to children, overall nutrition is a critical component of healthy development, and can vary widely based on a number of factors, including socioeconomic issues. Here, we are not endorsing the therapeutic use of vitamins. We merely suggest that measurement of vitamins could represent powerful biomarker tools for the detection and management of PAH, particularly in kids. It could be argued that vitamins cannot serve as biomarkers because they simply reflect nutritional adherence. In the strictest sense, vitamin D is not truly an essential dietary vitamin since it can be synthesized from stored skin cholesterol in adequate amounts by most mammals exposed to sunlight. Similarly, vitamin A is stored as retinol or as retinyl ester, can be converted to retinoic acid, and a role of retinoids in $\mathrm{PH}$ has been investigated (121). Thus, vitamin deficiencies have been shown to be associated with $\mathrm{PH}$, in some cases precede development of $\mathrm{PH}$, and their levels in anatomical compartments do not directly reflect nutritional adherence.

RNA. MicroRNAs (miRNAs) are non-coding single stranded RNAs that vary in length between 19 and $25 \mathrm{nt}$. Their function is to "fine-tune" the regulation of gene expression by affecting mRNA stability and translation into protein (122). MicroRNAs are implicated in lung diseases and have been identified as attractive biomarkers due to their accessibility and stability in bodily fluids (123). Circulating miRNAs are thought to be released from injured cells, though this is not always the case (124). At the time of this writing, there have been no studies measuring blood plasma miRNAs in children with PH. However, several studies have identified altered levels of miRNAs in buffy coat cells from patients with 
PAH (125), some of which showed good correlation to the disease severity. Additional studies have identified other miRNAs and, in animal models, manipulation of mir-204 (126) and mir-21 (127) showed dramatic therapeutic potential. These studies point to the urgent need to measure miRNAs in plasma and buffy cot cells form children with PAH. As has been a common theme throughout this review, caution must be exercised in the interpretation of any biomarker measurements in children. In the case of miRNAs, differential levels may be related to stage of development, gender differences, etc. Nevertheless, miRNAs may prove to be important and novel biomarkers in pediatric PAH.

\section{EXHALED BREATH BIOMARKERS}

Due its non-invasive nature, breath analysis has the potential to be a simple and convenient alternative to traditional biomarkers sources such as blood. Over 40 years ago, Linus Pauling used gas chromatography to identify volatile organic compounds (VOCs) in exhaled breath (128). The use of breath biomarkers has been standardized by law enforcement to measure ethanol consumption in automobile drivers. Exhaled breath consists of $\sim 500 \mathrm{~mL}$ of air, of which the first $150 \mathrm{~mL}$ does not participate in gas exchange (129). To detect VOC at the parts per million (or lower) level within the nitrogen, oxygen, carbon dioxide, water, and inert gas mixture, careful separation and identification is critical. VOC can derive from both exogenous sources (ex: pollutants) and endogenous biochemical processes. Here, we restrict our discussion of exhaled breath biomarkers to nitric oxide and VOC.

\section{Nitric oxide}

Nitric oxide (NO) is produced from the conversion of L-arginine to L-citrulline by a variety of lung resident cells as a result of the action of nitric oxide synthases (NOSs) (130). NO acts as a potent vasodilator but also inhibits vascular smooth muscle cell proliferation. Importantly, inhaled NO therapy is approved by the US Food and Drug Administration and European Medicine Evaluation Agency for the treatment of infants with persistent $\mathrm{PH}$ of the newborn who have acute hypoxemic respiratory failure (131). Clinically, the most extensively studied exhaled breath biomarker is fractional exhaled nitric oxide $\left(\mathrm{FE}_{\mathrm{NO}}\right)$ (132). Despite technical problems with standardization of its measurement, $\mathrm{FE}_{\mathrm{NO}}$ is lower in patients with $\mathrm{PH}$ but rises in responders to therapy. Thus, serial $\mathrm{FE}_{\mathrm{NO}}$ measurement may be useful. The measurement of NO may be complicated by genetic predisposition. In a study of Aymaran children (Aymara are an indigenous native nation who live in the Andes and Altiplano regions of South America), exhaled NO was actually lower (133). Thus, children who are protected from hypoxic $\mathrm{PH}$ due to high altitude do not apparently require increased respiratory NO synthesis. This may be due to NO biosynthesis by endothelium NOS3, by airway epithelium via NOS2, and/or by non-adrenergic non-cholinergic nerves via NOS1 (134). NO deficiency is a major therapeutic target in $\mathrm{PH}$, primarily by stabilization of $3^{\prime}, 5^{\prime}$-cyclic guanosine monophosphate (cGMP) (phosphodiesterase type 5 inhibition) (135), and indirectly by prostacyclins and endothelin receptor antagonists (136). Indeed, a distinct class of emerging therapies for $\mathrm{PH}$ is based upon the antagonistic actions of asymmetric dimethylarginine (ADMA) regulating NO production (137). Elevated plasma ADMA has been shown to correlate to severity of idiopathic (138) and chronic thromboembolic PH in adults (139), and in children with congenital heart disease (140) and sickle cell disease with PH (141). Moreover, in one study of systemic heart failure associated with pulmonary venous hypertension, exhaled NO levels were in higher in hypertensives, but NO did not correlate to increased plasma ADMA (142). Therefore, plasma levels of the NO-ADMA axis may not be congruent with exhaled NO measures, making conclusions about biomarker utility somewhat murky. Despite the complexities of NO biology in the setting of $\mathrm{PH}$, serial measurement of exhaled NO will likely continue to be a biomarker, particularly as a measure of response to a variety of therapies to treat $\mathrm{PH}$.

Volatile organic compound. Recently, a mass spectrometry approach was used to identify several VOC that could distinguish $\mathrm{PH}$ patients from controls (143). In that study, exhaled ammonia was increased in $\mathrm{PH}$ patients and correlated with disease severity. Other studies have also demonstrated differences in endothelin-1, 6-keto PGF(1alpha), and NT-proBNP in exhaled breath condensates in individuals with $\mathrm{PH}$ compared to controls (144).

There has been a robust increase in the number of studies utilizing breath analysis in the past decade ("robust" as assessed by retrieval of 1301 articles in a January 2014 PubMed search for "exhaled biomarker," 1042 published from 2003 to 2014, with only 258 publications involving children). Several aspects of exhaled breath analysis in the clinical setting make it particularly attractive to apply to the pediatric patient population. Breath tests are non-invasive and, in many cases, highly repeatable. Children are quite amenable to breathing treatments when fitted with fun masks and when clinicians make it fun. The same approaches could be potentially used to diagnose pediatric $\mathrm{PAH}$ and to monitor its progression and/or response to therapy.

\section{URINARY BIOMARKERS}

Besides peripheral blood, additional biological fluids are available that could offer prognostic value in pediatric PAH. Recently, Cracowski et al. prospectively studied serum biomarkers and urinary $\mathrm{F}_{2}$-isoprostane in 110 adults with $\mathrm{PAH}$ (145). Only urinary $\mathrm{F}_{2}$-isoprostane is independently associated with an increased 3year hazard of death. Furthermore, urinary $\mathrm{F}_{2}$-isoprostane levels can be elevated in asymptomatic individuals predisposed to $\mathrm{PAH}$, suggesting that their measurement may herald early stages of the disease. The source of $\mathrm{F}_{2}$-isoprostanes is unknown, as is their relevance to pulmonary vascular remodeling and increased PA pressure. Known to have pro-inflammatory properties and direct effects on both smooth muscle cells and ECs, they are generally considered markers of oxidative stress. Urinary $\mathrm{F}_{2}$-isoprostane levels could be measured in children at diagnosis of $\mathrm{PH}$, and/or in children of families with histories of familial PAH who may be asymptomatic. Urinary cGMP levels were found to be higher in patients with $\mathrm{PAH}$ compared to asthma patients and controls (146). Urinary cGMP levels inversely correlated with cardiac index, likely a reflection of NO and BNP-related hemodynamic impairment. 


\section{SPECIFIC RECOMMENDATIONS TO APPLY ADULT PULMONARY HYPERTENSION BIOMARKERS TO CHILDREN}

Biomarkers have the potential to be utilized as tools for identification of disease phenotype, patient response to therapy, and disease pathophysiology. Currently, the roles of several biomarkers have been identified in the pathophysiology of adult PAH, yet further characterization of these markers needs to be validated, clinical methods standardized, and engineering refined for development of robust assays. This level of investigation is not mirrored in pediatric PAH. A very limited number of studies have been conducted on elucidating biomarkers in children with PAH. It cannot be overstated that biomarkers in children with PAH are likely to be even more differentially influenced by additional factors compared with adults with PAH. Such factors include, but are not limited to: degree of physical activity, age in years and/or stage of development, gender differences, and nutritional status. Currently, several hurdles need to be overcome before we can advance to earlier diagnosis, more accurate prognostication, and improved therapy in children with PAH. With the exception of PAH associated with congenital abnormality, the diagnosis of $\mathrm{PH}$ in children is usually delayed, as it is in adults. Therefore, the most powerful biomarkers would be those that would identify individuals for whom the development of PAH is imminent or who are asymptomatic. Second, we need more sensitive and accurate biomarkers of disease progression that take into account developmental changes. Finally, we need biomarkers to identify which children will respond more favorably to one therapy or combinations of therapies and to confirm efficacy. For example, as imaging becomes faster, more powerful, and more precise, we anticipate that it will play an increasingly important role as a biomarker tool. The use of multiple biomarker panels assessed in large multi-center collaborations to increase cohort sizes will change the current paradigm of 100s of studies on a few kids to a few studies on 100s of kids. We recently summarized the current approach and diagnostic classification of $\mathrm{PAH}$ in children, as based on discussions and recommendations from the Pediatric Task Force of the fifth World Symposium on Pulmonary Hypertension (WSPH) in Nice, France (147). We outline our perspective on the use of biomarkers with regard to the classification, etiology, epidemiology and survival, diagnosis, treatment goals, and treatment of pediatric PH. In future discussions, we hope to reach agreement on the widespread adoption of specific sets of biomarkers discussed in this review, with a particular focus on those already identified as informative in adults with PH. We speculate that such a paradigm shift in experimental approach will translate into a transformative understanding of the natural history of PH in children.

\section{AUTHOR CONTRIBUTIONS}

Melanie J. Dufva, Ryan P. Delaney, Kelley L. Colvin wrote sections of the review. D. Dunbar Ivy and Kurt R. Stenmark and Kelley L. Colvin edited the review. Michael E. Yeager conceived of, wrote, and edited the review.

\section{REFERENCES}

1. De Wolf D. Clinical practice: pulmonary hypertension in children. Eur J Pediatr (2009) 168(5):515-22. doi:10.1007/s00431-008-0920-x

2. Ivy D. Advances in pediatric pulmonary arterial hypertension. Curr Opin Cardiol (2012) 27(2):70-81. doi:10.1097/HCO.0b013e32835018cd
3. Oishi P, Datar SA, Fineman JR. Advances in the management of pediatric pulmonary hypertension. Respir Care (2011) 56(9):1314-39. doi:10.4187/ respcare.01297

4. Barst RJ, Ertel SI, Beghetti M, Ivy DD. Pulmonary arterial hypertension: a comparison between children and adults. Eur Respir J (2011) 37(3):665-77. doi:10.1183/09031936.00056110

5. Kyle WB. Pulmonary hypertension associated with congenital heart disease: a practical review for the pediatric cardiologist. Congenit Heart Dis (2012) 7(6):575-83. doi:10.1111/chd.12012

6. Abman SH, Ivy DD. Recent progress in understanding pediatric pulmonary hypertension. Curr Opin Pediatr (2011) 23(3):298-304. doi:10.1097/MOP. 0b013e3283464a52

7. Abman SH. Pulmonary hypertension in children: a historical overview. Pediatr Crit Care Med (2010) 11(2 Suppl):S4-9. doi:10.1097/PCC.0b013e3181c765f3

8. Rabinovitch M. Molecular pathogenesis of pulmonary arterial hypertension. J Clin Invest (2012) 122(12):4306-13. doi:10.1172/JCI60658

9. Rosenzweig EB, Widlitz AC, Barst RJ. Pulmonary arterial hypertension in children. Pediatr Pulmonol (2004) 38(1):2-22. doi:10.1002/ppul.20051

10. Gupta H, Ghimire G, Naeije R. The value of tools to assess pulmonary arterial hypertension. Eur Respir Rev (2011) 20(122):222-35. doi:10.1183/09059180. 00006911

11. Rosenzweig EB, Barst RJ. Pulmonary arterial hypertension in children: a medical update. Indian J Pediatr (2009) 76(1):77-81. doi:10.1007/s12098-0090032-2

12. Peacock AJ, Murphy NF, McMurray JJ, Caballero L, Stewart S. An epidemiological study of pulmonary arterial hypertension. Eur Respir J (2007) 30(1):104-9. doi:10.1183/09031936.00092306

13. Barst RJ, Ivy DD, Foreman AJ, McGoon MD, Rosenzweig EB. Four- and seven-year outcomes of patients with congenital heart disease-associated pulmonary arterial hypertension (from the REVEAL registry). Am J Cardiol (2013) 113(1):147-55. doi:10.1016/j.amjcard.2013.09.032

14. van Loon RL, Roofthooft MT, Hillege HL, ten Harkel AD, van Osch-Gevers M, Delhaas T, et al. Pediatric pulmonary hypertension in the Netherlands: epidemiology and characterization during the period 1991 to 2005. Circulation (2011) 124(16):1755-64. doi:10.1161/CIRCULATIONAHA.110.969584

15. Haworth SG, Hislop AA. Treatment and survival in children with pulmonary arterial hypertension: the UK Pulmonary Hypertension Service for Children 2001-2006. Heart (2009) 95(4):312-7. doi:10.1136/hrt.2008.150086

16. Barst RJ, McGoon MD, Elliott CG, Foreman AJ, Miller DP, Ivy DD. Survival in childhood pulmonary arterial hypertension: insights from the registry to evaluate early and long-term pulmonary arterial hypertension disease management. Circulation (2012) 125(1):113-22. doi:10.1161/CIRCULATIONAHA. 111.026591

17. Fraisse A, Jais X, Schleich JM, di Filippo S, Maragnès P, Beghetti M, et al. Characteristics and prospective 2-year follow-up of children with pulmonary arterial hypertension in France. Arch Cardiovasc Dis (2010) 103(2):66-74. doi:10.1016/j.acvd.2009.12.001

18. Fasnacht MS, Tolsa JF, Beghetti M; Swiss Society for Pulmonary Arterial Hypertension. The Swiss registry for pulmonary arterial hypertension: the paediatric experience. Swiss Med Wkly (2007) 137(35-36):510-3.

19. Berger RM, Beghetti M, Humpl T, Raskob GE, Ivy DD, Jing ZC, et al. Clinical features of paediatric pulmonary hypertension: a registry study. Lancet (2012) 379(9815):537-46. doi:10.1016/S0140-6736(11)61621-8

20. Rosenzweig EB, Barst RJ. Idiopathic pulmonary arterial hypertension in children. Curr Opin Pediatr (2005) 17(3):372-80. doi:10.1097/01.mop. 0000163356.51027.c1

21. Badesch DB, Raskob GE, Elliott CG, Krichman AM, Farber HW, Frost AE, et al. Pulmonary arterial hypertension: baseline characteristics from the REVEAL registry. Chest (2010) 137(2):376-87. doi:10.1378/chest.09-1140

22. Biomarkers Definition Working Group. Biomarkers and surrogate endpoints: preferred definitions and conceptual framework. Clin Pharmacol Ther (2001) 69:89-95. doi:10.1067/mcp.2001.113989

23. Cracowski JL, Leuchte HH. The potential of biomarkers in pulmonary arterial hypertension. Am J Cardiol (2012) 110(6 Suppl):32S-8S. doi:10.1016/j. amjcard.2012.06.014

24. Barrier M, Meloche J, Jacob MH, Courboulin A, Provencher S, Bonnet S. Today's and tomorrow's imaging and circulating biomarkers for pulmonary arterial hypertension. Cell Mol Life Sci (2012) 69(17):2805-31. doi:10.1007/s00018012-0950-4 
25. Foris V, Kovacs G, Tscherner M, Olschewski A, Olschewski H. Biomarkers in pulmonary hypertension: what do we know? Chest (2013) 144(1):274-83. doi:10.1378/chest.12-1246

26. Stacher E, Graham BB, Hunt JM, Gandjeva A, Groshong SD, McLaughlin VV, et al. Modern age pathology of pulmonary arterial hypertension. Am J Respir Crit Care Med (2012) 186(3):261-72. doi:10.1164/rccm.201201-0164OC

27. Guignabert C, Dorfmuller P. Pathology and pathobiology of pulmonary hypertension. Semin Respir Crit Care Med (2013) 34(5):551-9. doi:10.1055/s-00331356496

28. El Chami H, Hassoun PM. Immune and inflammatory mechanisms in pulmonary arterial hypertension. Prog Cardiovasc Dis (2012) 55(2):218-28. doi:10.1016/j.pcad.2012.07.006

29. Savai R, Pullamsetti SS, Kolbe J, Bieniek E, Voswinckel R, Fink L, et al. Immune and inflammatory cell involvement in the pathology of idiopathic pulmonary arterial hypertension. Am J Respir Crit Care Med (2012) 186(9):897-908. doi:10.1164/rccm.201202-0335OC

30. Heresi GA, Aytekin M, Hammel JP, Wang S, Chatterjee S, Dweik RA. Plasma interleukin-6 adds prognostic information in pulmonary arterial hypertension. Eur Respir J (2013). doi:10.1183/09031936.00164713

31. Soon E, Holmes AM, Treacy CM, Doughty NJ, Southgate L, Machado RD, et al. Elevated levels of inflammatory cytokines predict survival in idiopathic and familial pulmonary arterial hypertension. Circulation (2010) 122(9):920-7. doi:10.1161/CIRCULATIONAHA.109.933762

32. Yang D, Liu Z, Yang Z. Ghrelin and its relation with $\mathrm{N}$-terminal brain natriuretic peptide, endothelin-1 and nitric oxide in patients with idiopathic pulmonary hypertension. Cardiology (2013) 124(4):241-5. doi:10.1159/000348368

33. Carlomagno G, Messalli G, Melillo RM, Stanziola AA, Visciano C, Mercurio V, et al. Serum soluble ST2 and interleukin-33 levels in patients with pulmonary arterial hypertension. Int J Cardiol (2013) 168(2):1545-7. doi:10.1016/j.ijcard. 2013.04.051

34. Uz O, Kardesoglu E, Tas D, Acar G, Isilak Z, Yiginer O, et al. CA-125 level is associated with right ventricular echocardiographic parameters in patients with COPD. South Med J (2011) 104(9):624-8. doi:10.1097/SMJ.0b013e318229a55c

35. Takeda Y, Takeda Y, Tomimoto S, Tani T, Narita H, Kimura G. Bilirubin as a prognostic marker in patients with pulmonary arterial hypertension. BMC Pulm Med (2010) 10:22. doi:10.1186/1471-2466-10-22

36. Monahan K, Scott TA, Su YR, Lenneman CG, Zhao DX, Robbins IM, et al. Reproducibility of intracardiac and transpulmonary biomarkers in the evaluation of pulmonary hypertension. Pulm Circ (2013) 3(2):345-9. doi:10.4103/ 2045-8932.114762

37. Saggar R, Sitbon O. Hemodynamics in pulmonary arterial hypertension: current and future perspectives. Am J Cardiol (2012) 110(6 Suppl):9S-15S doi:10.1016/j.amjcard.2012.06.011

38. Galiè N, Hoeper MM, Humbert M, Torbicki A, Vachiery JL, Barbera JA, et al. Guidelines for the diagnosis and treatment of pulmonary hypertension: the task force for the diagnosis and treatment of pulmonary hypertension of the European Society of Cardiology (ESC) and the European Respiratory Society (ERS), endorsed by the International Society of Heart and Lung Transplantation (ISHLT). Eur Heart J (2009) 30(20):2493-537. doi:10.1093/eurheartj/ehp297

39. McLaughlin VV, Archer SL, Badesch DB, Barst RJ, Farber HW, Lindner JR, et al. ACCF/AHA 2009 expert consensus document on pulmonary hypertension: a report of the American College of Cardiology Foundation Task Force on Expert Consensus Documents and the American Heart Association: developed in collaboration with the American College of Chest Physicians, American Thoracic Society, Inc., and the Pulmonary Hypertension Association. Circulation (2009) 119(16):2250-94. doi:10.1161/CIRCULATIONAHA.109.192230

40. Sharkey SW. A Guide to Interpretation of Hemodynamic Data in the Coronary Care Unit. 1st ed. Philadelphia: Lippincott, Williams, and Wilkins (1997).

41. Humbert M, Gerry Coghlan J, Khanna D. Early detection and managemen of pulmonary arterial hypertension. Eur Respir Rev (2012) 21(126):306-12. doi:10.1183/09059180.00005112

42. Bossone E, D'Andrea A, D'Alto M, Citro R, Argiento P, Ferrara F, et al. Echocardiography in pulmonary arterial hypertension: from diagnosis to prognosis. J Am Soc Echocardiogr (2013) 26(1):1-14. doi:10.1016/j.echo.2012.10.009

43. Forfia PR, Vachiéry JL. Echocardiography in pulmonary arterial hypertension. Am J Cardiol (2012) 110(6 Suppl):16S-24S. doi:10.1016/j.amjcard.2012.06.012

44. Habib G, Torbicki A. The role of echocardiography in the diagnosis and management of patients with pulmonary hypertension. Eur Respir Rev (2010) 19(118):288-99. doi:10.1183/09059180.00008110
45. Mathai SC, Sibley CT, Forfia PR, Mudd JO, Fisher MR, Tedford RJ, et al. Tricuspid annular plane systolic excursion is a robust outcome measure in systemic sclerosis-associated pulmonary arterial hypertension. J Rheumatol (2011) 38(11):2410-8. doi:10.3899/jrheum.110512

46. Takatsuki S, Nakayama T, Jone PN, Wagner BD, Naoi K, Ivy DD, et al. Tissue Doppler imaging predicts adverse outcome in children with idiopathic pulmonary arterial hypertension. J Pediatr (2012) 161(6):1126-31. doi:10.1016/j.jpeds.2012.05.050

47. Rajagopalan N, Simon MA, Mathier MA, López-Candales A. Identifying right ventricular dysfunction with tissue Doppler imaging in pulmonary hypertension. Int J Cardiol (2008) 128(3):359-63. doi:10.1016/j.ijcard.2007.06.094

48. Huez S, Vachiéry JL, Unger P, Brimioulle S, Naeije R. Tissue Doppler imaging evaluation of cardiac adaptation to severe pulmonary hypertension. Am J Cardiol (2007) 100(9):1473-8. doi:10.1016/j.amjcard.2007.06.047

49. Gurudevan SV, Malouf PJ, Kahn AM, Auger WR, Waltman TJ, Madani M, et al. Noninvasive assessment of pulmonary vascular resistance using Doppler tissue imaging of the tricuspid annulus. J Am Soc Echocardiogr (2007) 20(10):1167-71. doi:10.1016/j.echo.2007.02.004

50. Devaraj A, Hansell DM. Computed tomography signs of pulmonary hypertension: old and new observations. Clin Radiol (2009) 64(8):751-60. doi:10.1016/ j.crad.2008.12.005

51. Grosse C, Grosse A. CT findings in diseases associated with pulmonary hypertension: a current review. Radiographics (2010) 30(7):1753-77. doi:10.1148/rg. 307105710

52. Devaraj A, Wells AU, Meister MG, Corte TJ, Wort SJ, Hansell DM. Detection of pulmonary hypertension with multidetector CT and echocardiography alone and in combination. Radiology (2010) 254(2):609-16. doi:10.1148/ radiol.09090548

53. Boerrigter B, Mauritz GJ, Marcus JT, Helderman F, Postmus PE, Westerhof N, et al. Progressive dilatation of the main pulmonary artery is a characteristic of pulmonary arterial hypertension and is not related to changes in pressure. Chest (2010) 138(6):1395-401. doi:10.1378/chest.10-0363

54. Revel MP, Faivre JB, Remy-Jardin M, Delannoy-Deken V, Duhamel A, Remy J. Pulmonary hypertension: ECG-gated 64-section CT angiographic evaluation of new functional parameters as diagnostic criteria. Radiology (2009) 250(2):558-66. doi:10.1148/radiol.2502080315

55. Katzberg RW, Haller C. Contrast-induced nephrotoxicity: clinical landscape. Kidney Int Suppl (2006) 69(100):S3-7. doi:10.1038/sj.ki.5000366

56. Suga K. Pulmonary function-morphologic relationships assessed by SPECTCT fusion images. Ann Nucl Med (2012) 26(4):298-310. doi:10.1007/s12149012-0576-5

57. Zöphel K, Bacher-Stier C, Pinkert J, Kropp J. Ventilation/perfusion lung scintigraphy: what is still needed? A review considering technetium-99mlabeled macro-aggregates of albumin. Ann Nucl Med (2009) 23(1):1-16. doi:10.1007/s12149-008-0187-3

58. Paffett ML, Hesterman J, Candelaria G, Lucas S, Anderson T, Irwin D, et al. Longitudinal in vivo SPECT/CT imaging reveals morphological changes and cardiopulmonary apoptosis in a rodent model of pulmonary arterial hypertension. PLoS One (2012) 7(7):e40910. doi:10.1371/journal.pone. 0040910

59. Lundgrin EL, Park MM, Sharp J, Tang WH, Thomas JD, Asosingh K, et al. Fasting 2-deoxy-2-[18F]fluoro-D-glucose positron emission tomography to detect metabolic changes in pulmonary arterial hypertension hearts over 1 year. Ann Am Thorac Soc (2013) 10(1):1-9. doi:10.1513/AnnalsATS.201206-029OC

60. Wang L, Zhang Y, Yan C, He J, Xiong C, Zhao S, et al. Evaluation of right ventricular volume and ejection fraction by gated (18)F-FDG PET in patients with pulmonary hypertension: comparison with cardiac MRI and CT. J Nucl Cardiol (2013) 20(2):242-52. doi:10.1007/s12350-013-9672-8

61. Fang W, Zhao L, Xiong CM, Ni XH, He ZX, He JG, et al. Comparison of 18F-FDG uptake by right ventricular myocardium in idiopathic pulmonary arterial hypertension and pulmonary arterial hypertension associated with congenital heart disease. Pulm Circ (2012) 2(3):365-72. doi:10.4103/20458932.101651

62. Hagan G, Southwood M, Treacy C, Ross RM, Soon E, Coulson J, et al. (18)FDG PET imaging can quantify increased cellular metabolism in pulmonary arterial hypertension: a proof-of-principle study. Pulm Circ (2011) 1(4):448-55. doi: $10.4103 / 2045-8932.93543$

63. Marsboom G, Wietholt C, Haney CR, Toth PT, Ryan JJ, Morrow E, et al. Lung ${ }^{18} \mathrm{~F}$-fluorodeoxyglucose positron emission tomography for diagnosis and 
monitoring of pulmonary arterial hypertension. Am J Respir Crit Care Med (2012) 185(6):670-9. doi:10.1164/rccm.201108-1562OC

64. Fahey FH, Treves ST, Adelstein SJ. Minimizing and communicating radiation risk in pediatric nuclear medicine. J Nucl Med Technol (2012) 40(1):13-24. doi:10.2967/jnumed.109.069609

65. Hoeper MM, Tongers J, Leppert A, Baus S, Maier R, Lotz J. Evaluation of right ventricular performance with a right ventricular ejection fraction thermodilution catheter and MRI in patients with pulmonary hypertension. Chest (2001) 120:502-7. doi:10.1378/chest.120.2.502

66. Roeleveld RJ, Vonk-Noordegraaf A, Marcus JT, Bronzwaer JG, Marques KM, Postmus PE, et al. Effects of epoprostenol on right ventricular hypertrophy and dilatation in pulmonary hypertension. Chest (2004) 125:572-9. doi:10.1378/chest.125.2.572

67. Vonk-Noordegraaf A, Marcus JT, Holverda S, Roseboom B, Postmus PE. Early changes of cardiac structure and function in COPD patients with mild hypoxemia. Chest (2005) 127:1898-903. doi:10.1378/chest.127.6.1898

68. Vonk-Noordegraaf A, Marcus JT, Roseboom B, Postmus PE, Faes TJ, de Vries $\mathrm{PM}$. The effect of right ventricular hypertrophy on left ventricular ejection fraction in pulmonary emphysema. Chest (1997) 112:640-5. doi:10.1378/chest. 112.3.640

69. van Wolferen SA, Marcus JT, Boonstra A, Marques KM, Bronzwaer JG, Spreeuwenberg MD, et al. Prognostic value of right ventricular mass, volume, and function in idiopathic pulmonary arterial hypertension. Eur Heart J (2007) 28:1250-7. doi:10.1093/eurheartj/ehl477

70. Dimitroulas T, Mavrogeni S, Kitas GD. Imaging modalities for the diagnosis of pulmonary hypertension in systemic sclerosis. Nat Rev Rheumatol (2012) 8(4):203-13. doi:10.1038/nrrheum.2012.2

71. Grothues F, Moon JC, Bellenger NG, Smith GS, Klein HU, Pennell DJ. Interstudy reproducibility of right ventricular volumes, function, and mass with cardiovascular magnetic resonance. Am Heart J (2004) 147(2):218-23. doi:10.1016/j.ahj.2003.10.005

72. Surie S, Reesink HJ, Marcus JT, van der Plas MN, Kloek JJ, Vonk-Noordegraaf A, et al. Bosentan treatment is associated with improvement of right ventricular function and remodeling in chronic thromboembolic pulmonary hypertension. Clin Cardiol (2013) 36(11):698-703. doi:10.1002/clc.22197

73. Blalock S, Chan F, Rosenthal D, Ogawa M, Maxey D, Feinstein J. Magnetic resonance imaging of the right ventricle in pediatric pulmonary arterial hypertension. Pulm Circ (2013) 3(2):350-5. doi:10.4103/2045-8932.114763

74. Ibrahim el SH, White RD. Cardiovascular magnetic resonance for the assessment of pulmonary arterial hypertension: toward a comprehensive CMR exam. Magn Reson Imaging (2012) 30(8):1047-58. doi:10.1016/j.mri.2012.03.001

75. Hopkins SR, Wielpütz MO, Kauczor HU. Imaging lung perfusion. JAppl Physiol (1985) (2012) 113(2):328-39. doi:10.1152/japplphysiol.00320.2012

76. Moledina S, Pandya B, Bartsota M, Mortensen KH, McMillan M, Quyam S, et al. Prognostic significance of cardiac magnetic resonance imaging in children with pulmonary hypertension. Circ Cardiovasc Imaging (2013) 6(3):407-14. doi:10.1161/CIRCIMAGING.112.000082

77. Singhal S, Achary S, Mahajan S, Wanjari A, Agarwal A. Stem cells and lung diseases. J Assoc Physicians India (2011) 59:433-6.

78. Duong HT, Erzurum SC, Asosingh K. Pro-angiogenic hematopoietic progenitor cells and endothelial colony-forming cells in pathological angiogenesis of bronchial and pulmonary circulation. Angiogenesis (2011) 14(4):411-22. doi:10.1007/s10456-011-9228-y

79. Tuder RM, Cool CD, Yeager M, Taraseviciene-Stewart L, Bull TM, Voelkel NF. The pathobiology of pulmonary hypertension. Endothelium. Clin Chest Med (2001) 22(3):405-18. doi:10.1016/S0272-5231(05)70280-X

80. Smadja DM, Gaussem P, Mauge L, Israël-Biet D, Dignat-George F, Peyrard S, et al. Circulating endothelial cells: a new candidate biomarker of irreversible pulmonary hypertension secondary to congenital heart disease. Circulation (2009) 119(3):374-81. doi:10.1161/CIRCULATIONAHA.108.808246

81. Fadini GP, Avogaro A, Ferraccioli G, Agostini C. Endothelial progenitors in pulmonary hypertension: new pathophysiology and therapeutic implications. Eur Respir J (2010) 35(2):418-25. doi:10.1183/09031936.00112809

82. Amabile N, Guignabert C, Montani D, Yeghiazarians Y, Boulanger CM, Humbert M. Cellular microparticles in the pathogenesis of pulmonary hypertension. Eur Respir J (2013) 42(1):272-9. doi:10.1183/09031936.00087212

83. Levy M, Bonnet D, Mauge L, Celermajer DS, Gaussem P, Smadja DM. Circulating endothelial cells in refractory pulmonary hypertension in children: markers of treatment efficacy and clinical worsening. PLoS One (2013) 8(6):e65114. doi:10.1371/journal.pone.0065114

84. Smadja DM, Gaussem P, Mauge L, Lacroix R, Gandrille S, Remones V, et al. Comparison of endothelial biomarkers according to reversibility of pulmonary hypertension secondary to congenital heart disease. Pediatr Cardiol (2010) 31(5):657-62. doi:10.1007/s00246-010-9674-0

85. Smadja DM, Mauge L, Gaussem P, d'Audigier C, Israel-Biet D, Celermajer DS, et al. Treprostinil increases the number and angiogenic potential of endothelial progenitor cells in children with pulmonary hypertension. Angiogenesis (2011) 14(1):17-27. doi:10.1007/s10456-010-9192-y

86. Schiavon M, Fadini GP, Lunardi F, Agostini C, Boscaro E, Calabrese F, et al. Increased tissue endothelial progenitor cells in end-stage lung diseases with pulmonary hypertension. J Heart Lung Transplant (2012) 31(9):1025-30. doi:10.1016/j.healun.2012.06.005

87. Tantawy AA, Adly AA, Ismail EA, Habeeb NM. Flow cytometric assessment of circulating platelet and erythrocytes microparticles in young thalassemia major patients: relation to pulmonary hypertension and aortic wall stiffness. Eur J Haematol (2013) 90(6):508-18. doi:10.1111/ejh.12108

88. Visovatti SH, Hyman MC, Bouis D, Neubig R, McLaughlin VV, Pinsky DJ. Increased CD39 nucleotidase activity on microparticles from patients with idiopathic pulmonary arterial hypertension. PLoS One (2012) 7(7):e40829. doi:10.1371/journal.pone.0040829

89. Edwards AL, Gunningham SP, Clare GC, Hayman MW, Smith M, Frampton $\mathrm{CM}$, et al. Professional killer cell deficiencies and decreased survival in pulmonary arterial hypertension. Respirology (2013) 18(8):1271-7. doi:10.1111/ resp. 12152

90. Perros F, Cohen-Kaminsky S, Gambaryan N, Girerd B, Raymond N, Klingelschmitt I, et al. Cytotoxic cells and granulysin in pulmonary arterial hypertension and pulmonary veno-occlusive disease. Am J Respir Crit Care Med (2013) 187(2):189-96. doi:10.1164/rccm.201208-1364OC

91. Lenna S, Farina AG, Martyanov V, Christmann RB, Wood TA, Farber HW, et al. Increased expression of endoplasmic reticulum stress and unfolded protein response genes in peripheral blood mononuclear cells from patients with limited cutaneous systemic sclerosis and pulmonary arterial hypertension. Arthritis Rheum (2013) 65(5):1357-66. doi:10.1002/art.37891

92. Yeager ME, Belchenko DD, Nguyen CM, Colvin KL, Ivy DD, Stenmark KR Endothelin-1, the unfolded protein response, and persistent inflammation: role of pulmonary artery smooth muscle cells. Am J Respir Cell Mol Biol (2012) 46(1):14-22. doi:10.1165/rcmb.2010-0506OC

93. Yeager ME, Nguyen CM, Belchenko DD, Colvin KL, Takatsuki S, Ivy DD, et al. Circulating fibrocytes are increased in children and young adults with pulmonary hypertension. Eur Respir J (2012) 39(1):104-11. doi:10.1183/ 09031936.00072311

94. Yeager ME, Nguyen CM, Belchenko DD, Colvin KL, Takatsuki S, Ivy DD, et al. Circulating myeloid-derived suppressor cells are increased and activated in pulmonary hypertension. Chest (2012) 141(4):944-52. doi:10.1378/chest.11-0205

95. Dereddy N, Huang J, Erb M, Guzel S, Wolk JH, Sett SS, et al. Associated inflammation or increased flow-mediated shear stress, but not pressure alone, disrupts endothelial caveolin-1 in infants with pulmonary hypertension. Pulm Circ (2012) 2(4):492-500. doi:10.4103/2045-8932.105038

96. Morice AH, Pepke-Zaba J, Brown MJ, Thomas PS, Higenbottam TW. Atrial natriuretic peptide in primary pulmonary hypertension. Eur Respir J (1990) 3(8):910-3.

97. Hall S, Brogan P, Haworth SG, Klein N. Contribution of inflammation to the pathology of idiopathic pulmonary arterial hypertension in children. Thorax (2009) 64(9):778-83. doi:10.1136/thx.2008.106435

98. Bernus A, Wagner BD, Accurso F, Doran A, Kaess H, Ivy DD. Brain natriuretic peptide levels in managing pediatric patients with pulmonary arterial hypertension. Chest (2009) 135(3):745-51. doi:10.1378/chest.08-0187

99. Lammers AE, Hislop AA, Haworth SG. Prognostic value of B-type natriuretic peptide in children with pulmonary hypertension. Int J Cardiol (2009) 135(1):21-6. doi:10.1016/j.ijcard.2008.03.009

100. Fijalkowska A, Kurzyna M, Torbicki A, Szewczyk G, Florczyk M, Pruszczyk $\mathrm{P}$, et al. Serum N-terminal brain natriuretic peptide as a prognostic parameter in patients with pulmonary hypertension. Chest (2006) 129(5):1313-21. doi:10.1378/chest.129.5.1313

101. Souza R, Jardim C, Julio Cesar Fernandes C, Silveira Lapa M, Rabelo R, Humbert M. NT-proBNP as a tool to stratify disease severity in pulmonary 
arterial hypertension. Respir Med (2007) 101(1):69-75. doi:10.1016/j.rmed. 2006.04.014

102. Torbicki A, Kurzyna M, Kuca P, Fijałkowska A, Sikora J, Florczyk M, et al. Detectable serum cardiac troponin $\mathrm{T}$ as a marker of poor prognosis among patients with chronic precapillary pulmonary hypertension. Circulation (2003) 108(7):844-8. doi:10.1161/01.CIR.0000084544.54513.E2

103. Lassus P, Turanlahti M, Heikkilä P, Andersson LC, Nupponen I, Sarnesto A, et al. Pulmonary vascular endothelial growth factor and Flt-1 in fetuses, in acute and chronic lung disease, and in persistent pulmonary hypertension of the newborn. Am J Respir Crit Care Med (2001) 164(10 Pt 1):1981-7. doi:10.1164/ajrccm.164.10.2012036

104. Duncan M, Wagner BD, Murray K, Allen J, Colvin K, Accurso FJ, et al. Circulating cytokines and growth factors in pediatric pulmonary hypertension. Mediators Inflamm (2012) 2012:143428. doi:10.1155/2012/143428

105. Yeager ME, Colvin KL, Everett AD, Stenmark KR, Ivy DD. Plasma proteomics of differential outcome to long-term therapy in children with idiopathic pulmonary arterial hypertension. Proteomics Clin Appl (2012) 6(5-6):257-67. doi:10.1002/prca.201100078

106. Nickel N, Kempf T, Tapken H, Tongers J, Laenger F, Lehmann U, et al. Growth differentiation factor-15 in idiopathic pulmonary arterial hypertension. Am J Respir Crit Care Med (2008) 178(5):534-41. doi:10.1164/rccm.2008022350C

107. Davie NJ, Schermuly RT, Weissmann N, Grimminger F, Ghofrani HA. The science of endothelin-1 and endothelin receptor antagonists in the management of pulmonary arterial hypertension: current understanding and future studies. Eur J Clin Invest (2009) 39(Suppl 2):38-49. doi:10.1111/j.1365-2362.2009. 02120.x

108. Kwon YS, Chi SY, Shin HJ, Kim EY, Yoon BK, Ban HJ, et al. Plasma C-reactive protein and endothelin-1 level in patients with chronic obstructive pulmonary disease and pulmonary hypertension. J Korean Med Sci (2010) 25(10):1487-91. doi:10.3346/jkms.2010.25.10.1487

109. Farha S, Sharp J, Asosingh K, Park M, Comhair SA, Tang WH, et al. Mast cell number, phenotype, and function in human pulmonary arterial hypertension. Pulm Circ (2012) 2(2):220-8. doi:10.4103/2045-8932.97609

110. Sungprem K, Khongphatthanayothin A, Kiettisanpipop P, Chotivitayatarakorn P, Poovorawan Y, Lertsapcharoen P. Serum level of soluble intercellular adhesion molecule-1 correlates with pulmonary arterial pressure in children with congenital heart disease. Pediatr Cardiol (2009) 30(4):472-6. doi:10.1007/ s00246-008-9374-1

111. Geraci M, Meyrick B. Genomics and proteomics of pulmonary vascular disease. Compr Physiol (2011) 1(1):467-83. doi:10.1002/cphy.c100031

112. Demir M, Uyan U, Keceoclu S, Demir C. The relationship between vitamin D deficiency and pulmonary hypertension. Prague Med Rep (2013) 114(3):154-61.

113. Henkens IR, Hazenoot T, Boonstra A, Huisman MV, Vonk-Noordegraaf A. Major bleeding with vitamin $\mathrm{K}$ antagonist anticoagulants in pulmonary hypertension. Eur Respir J (2013) 41(4):872-8. doi:10.1183/09031936.00039212

114. Iodice FG, Di Chiara L, Boenzi S, Aiello C, Monti L, Cogo P, et al. Cobalamin $\mathrm{C}$ defect presenting with isolated pulmonary hypertension. Pediatrics (2013) 132(1):e248-51. doi:10.1542/peds.2012-1945

115. Park JH, Lee JH, Jeong JO, Seong IW, Choi SW. Thiamine deficiency as a rare cause of reversible severe pulmonary hypertension. Int J Cardiol (2007) 121(1):e1-3. doi:10.1016/j.ijcard.2006.08.054

116. Rao SN, Chandak GR. Cardiac beriberi: often a missed diagnosis. J Trop Pediatr (2010) 56(4):284-5. doi:10.1093/tropej/fmp108

117. Kupari M, Rapola J. Reversible pulmonary hypertension associated with vitamin C deficiency. Chest (2012) 142(1):225-7. doi:10.1378/chest.11-1857

118. Bogaard HJ, Mizuno S, Guignabert C, Al Hussaini AA, Farkas D, Ruiter G, et al. Copper dependence of angioproliferation in pulmonary arterial hypertension in rats and humans. Am J Respir Cell Mol Biol (2012) 46(5):582-91. doi:10.1165/rcmb.2011-0296OC

119. Rhodes CJ, Wharton J, Howard L, Gibbs JS, Vonk-Noordegraaf A, Wilkins MR. Iron deficiency in pulmonary arterial hypertension: a potential therapeutic target. Eur Respir J (2011) 38(6):1453-60. doi:10.1183/09031936.00037711

120. Hampole CV, Mehrotra AK, Thenappan T, Gomberg-Maitland M, Shah SJ. Usefulness of red cell distribution width as a prognostic marker in pulmonary hypertension. Am J Cardiol (2009) 104(6):868-72. doi:10.1016/j.amjcard.2009. 05.016
121. Preston IR, Tang G, Tilan JU, Hill NS, Suzuki YJ. Retinoids and pulmonary hypertension. Circulation (2005) 111(6):782-90. doi:10.1161/01.CIR. 0000155254.86840 .47

122. Bartel DP. MicroRNAs: genomics, biogenesis, mechanism, and function. Cell (2004) 116(2):281-97. doi:10.1016/S0092-8674(04)00045-5

123. Rupani H, Sanchez-Elsner T, Howarth P. MicroRNAs and respiratory diseases. Eur Respir J (2013) 41(3):695-705. doi:10.1183/09031936.00212011

124. Xu J, Zhao J, Evan G, Xiao C, Cheng Y, Xiao J. Circulating microRNAs: novel biomarkers for cardiovascular diseases. J Mol Med (Berl) (2012) 90(8):865-75. doi:10.1007/s00109-011-0840-5

125. Wei C, Henderson H, Spradley C, Li L, Kim IK, Kumar S, et al. Circulating miRNAs as potential marker for pulmonary hypertension. PLoS One (2013) 8(5):e64396. doi:10.1371/journal.pone.0064396

126. Courboulin A, Paulin R, Giguère NJ, Saksouk N, Perreault T, Meloche J, et al. Role for miR-204 in human pulmonary arterial hypertension. J Exp Med (2011) 208(3):535-48. doi:10.1084/jem.20101812

127. Yang S, Banerjee S, Freitas AD, Cui H, Xie N, Abraham E, et al. miR-21 regulates chronic hypoxia-induced pulmonary vascular remodeling. Am J Physiol Lung Cell Mol Physiol (2012) 302(6):L521-9. doi:10.1152/ajplung.00316.2011

128. Pauling L, Robinson AB, Teranishi R, Cary P. Quantitative analysis of urine vapor and breath by gas-liquid partition chromatography. Proc Natl Acad Sci U S A (1971) 68(10):2374-6. doi:10.1073/pnas.68.10.2374

129. Phillips M. Breath tests in medicine. Sci Am (1992) 267(1):74-9. doi:10.1038/ scientificamerican0792-74

130. Barnes PJ, Dweik RA, Gelb AF, Gibson PG, George SC, Grasemann H, et al. Exhaled nitric oxide in pulmonary diseases: a comprehensive review. Chest (2010) 138(3):682-92. doi:10.1378/chest.09-2090

131. Abman SH. Inhaled nitric oxide for the treatment of pulmonary arterial hypertension. Handb Exp Pharmacol (2013) 218:257-76. doi:10.1007/978-3-64238664-0_11

132. van de Kant KD, van der Sande LJ, Jöbsis Q, van Schayck OC, Dompeling E. Clinical use of exhaled volatile organic compounds in pulmonary diseases: a systematic review. Respir Res (2012) 13:117. doi:10.1186/1465-9921-13-117

133. Stuber T, Sartori C, Salmòn CS, Hutter D, Thalmann S, Turini P, et al. Respiratory nitric oxide and pulmonary artery pressure in children of Aymara and European ancestry at high altitude. Chest (2008) 134(5):996-1000. doi:10.1378/chest.08-0854

134. Dweik RA, Laskowski D, Abu-Soud HM, Kaneko F, Hutte R, Stuehr DJ, et al. Nitric oxide synthesis in the lung. Regulation by oxygen through a kinetic mechanism. J Clin Invest (1998) 1013:660-6. doi:10.1172/JCI1378

135. Ozkan M, Dweik RA, Laskowski D, Arroliga AC, Erzurum SC. High levels of nitric oxide in individuals with pulmonary hypertension receiving epoprostenol therapy. Lung (2001) 1794:233-43. doi:10.1007/s004080000064

136. Girgis RE, Frost AE, Hill NS, Horn EM, Langleben D, McLaughlin VV, et al. Selective endothelin A receptor antagonism with sitaxsentan for pulmonary arterial hypertension associated with connective tissue disease. Ann Rheum Dis (2007) 6611:1467-72. doi:10.1136/ard.2007.069609

137. Böger RH. Asymmetric dimethylarginine (ADMA): a novel risk marker in cardiovascular medicine and beyond. Ann Med (2006) 38:126-36. doi:10.1080/ 0785389050047215

138. Kielstein JT, Bode-Böger SM, Hesse G, Martens-Lobenhoffer J, Takacs A, Fliser D, et al. Asymmetrical dimethylarginine in idiopathic pulmonary arterial hypertension. Arterioscler Thromb Vasc Biol (2005) 25(7):1414-8. doi:10.1161/ 01.ATV.0000168414.06853.f0

139. Skoro-Sajer N, Mittermayer F, Panzenboeck A, Bonderman D, Sadushi R, Hitsch $\mathrm{R}$, et al. Asymmetric dimethylarginine is increased in chronic thromboembolic pulmonary hypertension. Am J Respir Crit Care Med (2007) 176(11):1154-60. doi:10.1164/rccm.200702-278OC

140. Sanli C, Oguz D, Olgunturk R, Tunaoglu FS, Kula S, Pasaoglu H, et al. Elevated homocysteine and asymmetric dimethyl arginine levels in pulmonary hypertension associated with congenital heart disease. Pediatr Cardiol (2012) 33(8):1323-31. doi:10.1007/s00246-012-0321-9

141. El-Shanshory M, Badraia I, Donia A, Abd El-Hameed F, Mabrouk M. Asymmetric dimethylarginine levels in children with sickle cell disease and its correlation to tricuspid regurgitant jet velocity. Eur J Haematol (2013) 91(1):55-61. doi:10.1111/ejh.12114

142. Schuster A, Thakur A, Wang Z, Borowski AG, Thomas JD, Tang WH. Increased exhaled nitric oxide levels after exercise in patients with chronic 
systolic heart failure with pulmonary venous hypertension. J Card Fail (2012) 18(10):799-803. doi:10.1016/j.cardfail.2012.08.356

143. Cikach FS Jr, Tonelli AR, Barnes J, Paschke K, Newman J, Grove D, et al. Breath analysis in pulmonary arterial hypertension. Chest (2013). doi:10.1378/chest. 13-1363

144. Warwick G, Kotlyar E, Chow S, Thomas PS, Yates DH. Exhaled breath condensate in pulmonary arterial hypertension. J Breath Res (2012) 6(3):036006. doi:10.1088/1752-7155/6/3/036006

145. Cracowski JL, Degano B, Chabot F, Labarère J, Schwedhelm E, Monneret D, et al. Independent association of urinary F2-isoprostanes with survival in pulmonary arterial hypertension. Chest (2012) 142(4):869-76. doi:10.1378/chest. 11-1267

146. Bogdan M, Humbert M, Francoual J, Claise C, Duroux P, Simonneau G, et al. Urinary cGMP concentrations in severe primary pulmonary hypertension. Thorax (1998) 53(12):1059-62. doi:10.1136/thx.53.12.1059

147. Ivy DD, Abman SH, Barst RJ, Berger RM, Bonnet D, Fleming TR, et al. Pediatric pulmonary hypertension. J Am Coll Cardiol 2013 62(25 Suppl):D117-26.
Conflict of Interest Statement: The authors declare that the research was conducted in the absence of any commercial or financial relationships that could be construed as a potential conflict of interest.

Received: 11 November 2013; paper pending published: 22 December 2013; accepted: 21 January 2014; published online: 03 February 2014.

Citation: Colvin KL, Dufva MJ, Delaney RP, Ivy DD, Stenmark KR and Yeager ME (2014) Biomarkers for pediatric pulmonary arterial hypertension - a call to collaborate. Front. Pediatr. 2:7. doi: 10.3389/fped.2014.00007

This article was submitted to Pediatric Pulmonology, a section of the journal Frontiers in Pediatrics.

Copyright $\odot 2014$ Colvin, Dufva, Delaney, Ivy, Stenmark and Yeager. This is an openaccess article distributed under the terms of the Creative Commons Attribution License (CC BY). The use, distribution or reproduction in other forums is permitted, provided the original author(s) or licensor are credited and that the original publication in this journal is cited, in accordance with accepted academic practice. No use, distribution or reproduction is permitted which does not comply with these terms. 